\title{
Evaluation of some chemical disinfectant formulations against Pseudomonas and Staphylococcus species from poultry and poultry environment
}

\author{
Grillo, J. Adebayo and Olasupo, N. Ayoade
}

Department of Microbiology, Faculty of Science, Lagos State University, Lagos, Nigeria
Abstract:

Introduction: Diskol, lodasteryl and Morigad are disinfectant formulations commonly used in the poultry industry in Nigeria to prevent infections of birds.

Aims: The formulations were evaluated for effectiveness in controlling the growth of bacterial isolates from poultry and poultry environment.

Materials and Methods: The bacteria were isolated from water, feed, litter materials, and cloacae swabs, and were identified using the Analytical Profile Index kits. The disinfectant evaluation was carried out using the kill kinetics method at $0.5 \mathrm{X}, 1 \mathrm{X}$ and $1.5 \mathrm{X}$ the manufacturer's recommended dilutions.

Results: The pseudomonads had percentage occurrence of Pseudomonas putida (25) $>P$. mendocina $(20)>P$. aeruginosa (15), $P$. stutzeri (15), $P$. fluorescens $(15)>P$. shigelliodes $(10)$, while the staphylococci had Staphylococcus lentus $(78.26)>S$. sciuri $(13.04)>S$. aureus (8.70). Diskol and Morigad recorded $8 \log _{10} 10$ reduction (i.e. $100 \%$ kill) at the 3 concentrations against all the Pseudomonas isolates at 10 min contact time but were only able to achieve same at $1 \mathrm{X}$ and $1.5 \mathrm{X}$ against the staphylococci. At $0.5 \mathrm{X}$, however, both Diskol and Morigad were only able to achieve $8 \log 10$ reduction (100\% kill) of all Staphylococcus sp. at 30 min except against $S$. sciuri SN3 where Diskol achieved same record at $10 \mathrm{~min}$. The best performances of lodasteryl were less than $100 \%$ kill even at $8 \log 10$ reduction against $P$. putida FaF12, P. mendocina FaW48, $P$. stutzeri FaM35, and P. shigelliodes FbM36 at $1.5 \mathrm{X}$ and $60 \mathrm{~min}$ and $7.99 \log 10$ reduction at $1.5 \mathrm{X}$ and $60 \mathrm{~min}$ against $S$. lentus SN1, S. lentus SN2, S. sciuri SN3, S. sciuri SN4 and S. aureus SM2. All disinfectants demonstrated increasing activity with increase in time and concentration.

Conclusion: The study indicated the potential of the disinfectants in elimination of some bacteria of public health significance thus justifying their use in the control of poultry infections.

Keywords: Diskol, Morigad, lodasteryl, Pseudomonas, Staphylococcus, disinfectants, Poultry.

\section{Funding information}

Research work was self-sponsored

\section{orrespondence \\ Microbiology, Faculty of Science, Lagos \\ State University, Lagos, Nigeria \\ Email: jaagrillo@yahoo.com}




\section{INTRODUCTION}

Poultry farming is one of the important means of supplying the fast-growing global population with high quality protein and also providing incomes to farmers [1]. Poultry farming is one of the ways Africa has engaged to increase its production of animal protein. It offers the best yield in conversion of vegetable calories to high yield animal protein [2]. The world is experiencing an increasing incidence of food poisoning caused by the contamination of food by pathogenic microorganisms with the attendant adverse effects on health and socio - economic life of the people [3,4]. There is, therefore, an unprecedented concern for food safety by the general public (the consumers) and the food industry [5]. Of major Importance among sources of microbial infection and contamination of poultry birds, poultry products and environment are the faeces, feed, water, water troughs, air, and floor of poultry house.

Birds that enter the processing line already contaminated with microorganisms will provide a veritable source of contamination of the final products. Live birds may shed microorganisms into feed, water, floor, transport containers and in faeces, thereby causing re-infection of other birds [5]. If poultry houses and transport containers are not properly cleaned and disinfected, they may act as continuous culture system where the microorganisms deposited in previous trips will reside and multiply to contaminate subsequent flocks or batches housed in the same farm or transported in the same unclean container [5,6]. Once chickens are exposed to infection, the poultry flock is colonized quickly. The infected chickens may lead to meat contamination during slaughtering. Therefore, a farm-level disinfection program is needed to eliminate microbial infection and poultry food poisoning.

Disinfection in poultry farms and by poultry workers is essential in order to reduce financial losses due to disease outbreaks. Proper disinfection reduces the likelihood of infection of flocks and workers. Disinfection is an essential component of the biosecurity program for the poultry industry [7]. Mounting concern over the potential for microbial contamination and infection risks in the food and general consumer markets have also led to increased usage of antiseptics and disinfectants by the general public [5].

The increasing reports of food borne diseases and nosocomial infections have not only suggested an exaggerated belief in the effectiveness of disinfection procedures [8] but more importantly have increased interest in the evaluation of effectiveness of disinfectants in destroying pathogens and microbial contaminants [9]. Members of the genera; Pseudomonas and Staphylococcus have been implicated in poultry infections in other climes of the world, but there is dearth of information in literature, in Nigeria, on the distribution of Pseudomonas and Staphylococcus in poultry and poultry environment. In addition, the standardization of disinfection program for poultry industry is practically non - existent in Nigeria. Therefore, the present study evaluated three disinfectant formulations, commonly used in the poultry industry in Nigeria, for their effectiveness in controlling the growth of Pseudomonas and Staphylococcus species.

\section{MATERIAL AND METHODS}

\subsection{Preparation of test concentrations of the chemical disinfectants}

Diskol is a synergistic blend of a quaternary ammonium compound and two aldehydes to give the formulation; Benzalkonium chloride $5 \%$, glutaraldehyde $7.5 \%$ and formaldehyde $7 \%$. The recommended concentration (1X) was 2:100 (2 ml of Diskol solution was added to $98 \mathrm{ml}$ of distilled water, $\mathrm{pH}$ 8.7). The $50 \%$ below recommended concentration $(0.5 \mathrm{X})$ was prepared by adding $1 \mathrm{ml}$ of Diskol solution to $99 \mathrm{ml}$ of distilled water and shaken to homogenize. The $50 \%$ above recommended dilution (1.5X) was prepared by adding $3 \mathrm{ml}$ of Diskol solution to $97 \mathrm{ml}$ distilled water.

Morigad contains $32 \%$ Phenol v/v and $1 \mathrm{X}$ was 1:111 (1 $\mathrm{ml}$ of Morigad solution was added to $110 \mathrm{ml}$ of distilled water,). To obtain the $0.5 \mathrm{X}, 0.5 \mathrm{ml}$ Morigad solution was added to $110.5 \mathrm{ml}$ distilled water. For the $1.5 \mathrm{X}$, $1.5 \mathrm{ml}$ Morigad solution was added to $109.5 \mathrm{ml}$ distilled water.

lodasteryl is a solution of active iodine $55 \mathrm{mg} / 100 \mathrm{ml}$ and $1 \mathrm{X}$ was $0.1: 100(0.1 \mathrm{ml}$ of lodasteryl solution was added to $99.9 \mathrm{ml}$ of distilled water,). The $0.5 \mathrm{X}$ was prepared by adding $0.05 \mathrm{ml}$ lodasteryl solution to $99.95 \mathrm{ml}$ distilled water. For the $1.5 \mathrm{X}, 0.15 \mathrm{ml}$ lodasteryl solution was added to $99.85 \mathrm{ml}$ distilled water.

\subsubsection{Collection of samples}

The Aiyedooto Poultry Farm Settlement (comprising 30 poultry farms) in Ojo, Lagos State, Southwestern Nigeria was used as the sampling site. Triplicate samples each of water, feed (layer's feed), litter material (which consisted of wood shavings), and cloacae swabs (of layer birds) were taken from six different farms in the settlement. The water samples were aseptically collected from the tits, troughs, and the reservoir tank. Cloacae swabs were collected using sterile swab sticks pre - moistened in peptone water. Both the water and cloacae swab samples were placed in an insulating foam box containing ice. All the samples were immediately transported to the laboratory within one hour for analysis. 


\subsection{Bacterial isolation and identification}

Ten grams each of the feed and litter material was separately homogenized with $90 \mathrm{ml}$ sterile water in a sterilized blender to make the $10^{-1}$ dilution. This was serially diluted to $10^{-6}$ dilution and then $1 \mathrm{ml}$ of appropriate dilution was separately inoculated on mannitol salt agar, nutrient agar and pseudomonas $\mathrm{CN}$ agar. The water samples $(1 \mathrm{ml})$ were directly pourplated on each of the three media. The swabs were cultured by spread plate method onto the three media. All cultured plates were aerobically incubated at $37^{\circ} \mathrm{C}$ for $24 \mathrm{~h}$. distinct colonies were subcultured twice to obtain pure cultures, which were stored as stock cultures in nutrient agar slants in the refrigerator at $4^{\circ} \mathrm{C}$ till further analysis The isolates were identified with the method of [10] on colonial and cellular morphology. Isolates from the mannitol salt agar and nutrient agar that were Gram positive cocci in clusters and catalase positive were selected as presumable Staphylococcus strains and were further characterized using the analytical profile index (API) kits of API STAPH (BioMerieux) while, isolates from the pseudomonas $\mathrm{CN}$ agar and nutrient agar that were Gram negative bacilli, oxidase positive and catalase positive were selected as presumable Pseudomonas strains and were further identified using API 20NE (BioMerieux).

\subsubsection{Evaluation of the chemical disinfectants against the bacterial isolates}

Evaluation of disinfectant was carried out using Suspension kill kinetics method of [11] with few modifications. Four milliliters of a 16 - $24 \mathrm{~h}$ tryptone soy broth culture of each test organism was added to $96 \mathrm{ml}$ phosphate buffered saline (PBS, $0.33 \mathrm{M} \mathrm{NaCl}, 3$ $\mathrm{mM} \mathrm{KCl}, 8.4 \mathrm{mM} \mathrm{Na} \mathrm{HPO}_{4}, 1.6 \mathrm{mM} \mathrm{KH}_{2} \mathrm{PO}_{4}, \mathrm{pH}$ 7.2) and the bacterial cell density was spectrophotometrically adjusted with PBS to $10^{8}$ $\mathrm{cfu} / \mathrm{ml}$. Aliquot amount of $2.5 \mathrm{ml}$ was taken from each test organism suspension and mixed with $2.5 \mathrm{ml}$ of each concentration of disinfectant solution to make a 5 $\mathrm{ml}$ organism - disinfectant mixture. At intervals of 10 , 20,30 , and 60 minutes, $1 \mathrm{ml}$ of the test mixture was transferred to $9 \mathrm{ml}$ of $3 \%$ Tween 80 solution (to neutralize the disinfectant) and allowed to stand for 5 min. Aliquot amount of $1 \mathrm{ml}$ was taken from each test mixture - neutralizer tube and inoculated onto standard plate count agar by pour plate method and incubated at $37^{\circ} \mathrm{C}$ for $24 \mathrm{~h}$ to determine the population of surviving viable cells in $\mathrm{cfu} / \mathrm{ml}$.

\subsubsection{Statistical analysis}

Statistical analysis of the log reduction values of population of surviving cells was performed using the analysis of variance (ANOVA) 2 factor without replication at the significance level 0.05 . Statistical difference was detected as $\mathrm{P}<0.05$.

\section{RESULTS}

\subsection{Occurrence and distribution of Pseudomonads and Staphylococci}

The API 20NE results indicated the following degree of homology (\% ID), P. putida (97.9), P. mendocina (97.6), P. fluorescens (98.9), $P$. stutzeri (97.7), $P$. aeruginosa (99.8) and $P$. shigelliodes (96.5) while API STAPH indicated the following; S. lentus (99.2), $S$. aureus (97.8) and $S$. sciuri (99.9). Table 1 show that Pseudomonas putida had the highest percentage occurrence of 25 among the isolated Pseudomonads followed by $P$. mendocina (20), $P$. aeruginosa (15), $P$. stutzeri (15). The lowest \% occurrence among the pseudomonads was 10 for $P$. shigelliodes. For the staphylococci, Staphylococcus lentus had the highest percentage occurrence of 78.26 , followed by $S$. sciuri (13.04) and the least \% occurrence was 8.70 for $S$. aureus. All the samples, except litter material, contained $P$. putida and $P$. mendocina. Pseudomonas stutzeri was found only found in the feed and litter material while $P$. aeruginosa was present in all the samples except the feed. Litter material is the only sample with $P$. shigelliodes. All the samples contained $S$. lentus but the feed had the highest distribution of the organism at 10. Staphylococcus sciuri was found in all the samples except cloacae swab and $S$. aureus was not present in drinking water and cloacae swabs.

Table 1: occurrence of pseudomonas and staphylococcus species in different poultry and poultry sources

\begin{tabular}{|c|c|}
\hline Sample & Species occurrence \\
\hline \multicolumn{2}{|r|}{ Pseudomonas } \\
\hline Drinking water & $\begin{array}{l}P . \text { putida }(4), P \text {. mendocina }(3), P \text {. } \\
\text { aeruginosa (1) }\end{array}$ \\
\hline Feed & $\begin{array}{l}P . \text { putida (4), } P \text {. mendocina (3), } P \text {. } \\
\text { stutzeri (3) }\end{array}$ \\
\hline Litter material & $\begin{array}{l}P . \text { aeruginosa }(3), P \text {. stutzeri }(3), P \text {. } \\
\text { shigelliodes }(4)\end{array}$ \\
\hline Cloacae swab & $\begin{array}{l}P . \text { putida }(2), P . \text { aeruginosa }(2), P . \\
\text { fluorescens }(6), P . \text { mendocina }(2)\end{array}$ \\
\hline \multicolumn{2}{|c|}{ Staphylococcus sp. } \\
\hline Drinking water & S. lentus (4), S. sciuri (1) \\
\hline Feed & $\begin{array}{l}\text { S. lentus (10), S. aureus (1), } S . \\
\text { sciuri }(1)\end{array}$ \\
\hline Litter material & $\begin{array}{l}\text { S. lentus (2), S. aureus (1), S. sciuri } \\
\text { (1) }\end{array}$ \\
\hline Cloacae swab & S. lentus (2) \\
\hline
\end{tabular}




\subsubsection{Effects of disinfectants on the Pseudomonas and Staphylococcus isolates}

The results in Fig $1-6$ show that Diskol and Morigad recorded $8 \log _{10} 10$ reduction (i.e. $100 \%$ kill) at the 3 concentrations against all the Pseudomonas isolates at $10 \mathrm{~min}$ contact time but were only able to achieve same at $1 \mathrm{X}$ and $1.5 \mathrm{X}$ against the staphylococci. At $0.5 \mathrm{X}$, however, both Diskol and Morigad were only able to achieve $8 \log 10$ reduction (100\% kill) of all Staphylococcus sp. at 30 min except against S. sciuri SN3 where Diskol achieved same record at $10 \mathrm{~min}$. The best performance of lodasteryl against the pseudomonads was less than $100 \%$ kill even at 8 log 10 reduction against $P$. putida $\mathrm{FaF} 12, P$. mendocina FaW48, $P$. stutzeri FaM35, and $P$. shigelliodes FbM36 at $1.5 \mathrm{X}$ and $60 \mathrm{~min}$. At this concentration and time, lodasteryl was least effective against $P$. aeruginosa FbW30 with $7.99 \log 10$ reduction.. Against the staphylococci, lodasteryl's best was 7.99log 10 reduction at $1.5 \mathrm{X}$ and 60 min against $S$. lentus $\mathrm{SN} 1$, S. lentus SN2, S. sciuri SN3, S. sciuri SN4 and S.

The predominance of $P$. putida, P. mendocina and $S$. lentus in the different samples from layer birds and poultry environment (Table 1) is in conformity with the reports of [13] who isolated Staphylococcus sp. from poultry litter and [14] who isolated $P$. fluorescens, $P$. aeruginosa, $S$. aereus and Staphylococcus sp. from poultry faeces. However, P. mendocina, P. stutzeri, $P$. shigelliodes, $S$. lentus and $S$. scuiri were isolated in this study but not reported by [14]. This difference may be due to the fact that [14] limited their samples to only faeces. In this study, $P$. aeruginosa was not found in feed but [15] reported the organism in feed. Differences in feed quality, feed storage and handling are possible explanation for such difference. The presence of $P$. aeruginosa and $S$. aureus among the isolates recorded in this study underscores the importance of proper disinfection in the poultry industry since these two organisms are potential opportunistic pathogens of man.

Diskol and Morigad showed high degree of efficacy against all the test bacteria. The outcomes of this study accord with [16] who reported that glutaraldehyde and Benzalkonium chloride respectively yielded effective disinfectant activity against Pseudomonas sp. in less than $10 \mathrm{~min}$ of exposure. Glutaraldehyde was also reported to exert significant antimicrobial activity against planktonic bacteria [17]. The result is also consistent with the report of [18] that Microzal (combination of quaternary ammonium compound and glutaraldehyde) and Incospect (combination of quaternary ammonium compound, glutaraldehyde and formalin) achieved $100 \%$ kill against Pseudomonas aeruginosa after 5 min. Diskol proved the most effective of the three disinfectant formulations used in this study. The bacterial population reductions by Diskol and Morigad were significantly $(P<0.05)$ greater than that of lodasteryl but there was no significant difference between the bacterial population reductions by Diskol aureus SM2. It was least effective at $0.5 \mathrm{X}$ and $10 \mathrm{~min}$ against $S$. aureus SM2 with $7.72 \log 10$ reduction. All disinfectants demonstrated increasing activity with increase in time and concentration.

\subsection{DISCUSSION}

Disinfectants are widely used in several fields for disease prevention and control [12] and they have become an integral part of modern livestock and poultry farms [7]. The efficacy of disinfectants is affected by disinfectant type, formulation, mode of application, exposure time, concentration, natural microbial population, surfaces, and temperature. This study provides insight into the occurrence and distribution of Pseudomonas and Staphylococcus species in poultry (Layer chicken) and poultry environments in a farm settlement in Lagos state and the effectiveness of three chemical disinfectants (commonly used by poultry farmers in the area) in controlling the growth of the bacteria under different conditions of concentration and contact times $(10,20$, 30 , and $60 \mathrm{~min}$ ).

and Morigad except at the $0.5 \mathrm{X}$. This promising disinfecting ability of Diskol is most probably the result of its unique formulation, comprising a synergistic combination of three compounds; Benzalkonium chloride $5 \%$, glutaraldehyde $7.5 \%$ and formaldehyde $7 \%$. The use of two or more active ingredients in commercial disinfectants is expected to increase the antibacterial effect of these products [19] and this explains why products containing quaternary ammonium and glutaraldehyde (and / or another aldehyde) have been the most widely used for disinfection of poultry houses.

Morigad (32\% phenol $\mathrm{v} / \mathrm{v}$ ) also proved to be very effective against the test bacteria in this study. The bacterial population reductions by Morigad were significantly greater than those for lodasteryl. Two phenolic formulations, termed Phenol 1 and Phenol 2 were reported with antibacterial activity against $E$. coli and coliforms isolated from poultry floor dirt [19]. Phenol has the ability to cause leakage of intracellular materials when used at low concentrations and coagulation of both enzymatic and structural proteins (including cell membranes) at higher concentrations $(20 ; 21]$.

lodasteryl (active iodine $55 \mathrm{mg} / 100 \mathrm{ml}$ ) was the least effective of the three disinfectants studied. The best performance of lodasteryl against the pseudomonads was less than $100 \%$ kill even at $8 \log 10$ reduction against $P$. putida FaF12, $P$. mendocina FaW48, $P$. stutzeri FaM35, and $P$. shigelliodes FbM36 at $1.5 \mathrm{X}$ and $60 \mathrm{~min}$. Against the staphylococci, lodasteryl did not achieve $8 \log 10$ reduction. Against all the test bacteria, lodasteryl could not achieve $100 \%$ kill. The performance of lodasteryl in this study was consistent with the report of [22] that iodine was unable to achieve 100\% efficiency against Pseudomonas sp. 
[19] reported poor disinfecting ability of iodine (1:320) against total and fecal coliforms. Also [18] reported lower activity of povidone iodine against bacteria.

However, lodasteryl activity in this present study was better than that reported by [19]. Apart from the different dilutions and test bacteria, experimental conditions may also be responsible for this difference.

Diskol, Morigad and lodasteryl demonstrated significantly increasing inhibitory activity with increase in time and concentration. This is further supported by earlier reports $[8,23,24]$ showing that the antimicrobial activities of disinfectants are concentration dependent.

The Pseudomonas isolates demonstrated more susceptibility to all the test disinfectants than the Staphylococcus species. This is at variance with many reports that Gram negative bacteria are generally less susceptible to disinfectants than Gram positive bacteria. However, [17] has reported that $P$. fluorescens biofilms were more susceptible to glutaraldehyde than Bacillus cereus biofilms. This present result may be explained by the fact that, different microbial strains are influenced by different external factors, such as transfer of resistance genes, physiological injuries due to prolonged use, previous exposure to underdosage of disinfectants which may lead to the development of varying levels of resistance. Care and caution is necessary in the handling of disinfectants. Benzalkonium chloride, which is generally non - irritating, was reported to cause irritation of the middle ear tissue [25]. Phenol and its vapours are corrosive to the eyes, skin, and the respiratory tract but, it is not known to be carcinogenic [26]. Formaldehyde is not acutely toxic but, could be irritating to the eyes and mucous membrane on long term exposure. Glutaraldehyde is toxic and a strong irritant but, there is no evidence of carcinogenic activity [27]. The use of gloves, nose masks, goggles, proper handling and avoidance of undue exposure are measures to ensure safety in handling of disinfectants.
A

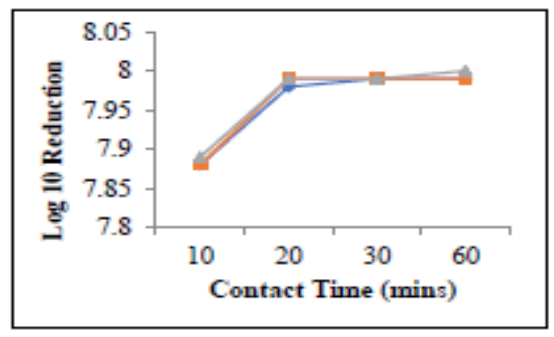

D

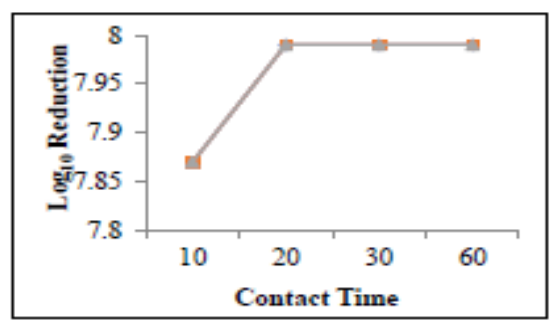

口 $=0.5 \mathrm{x}, \mathrm{x}=1 \mathrm{x}, \quad \Delta=1.5 \mathrm{x}$
B

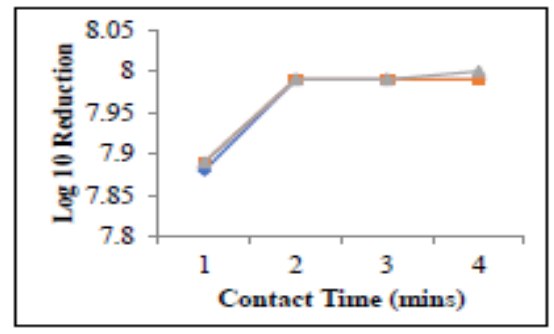

E

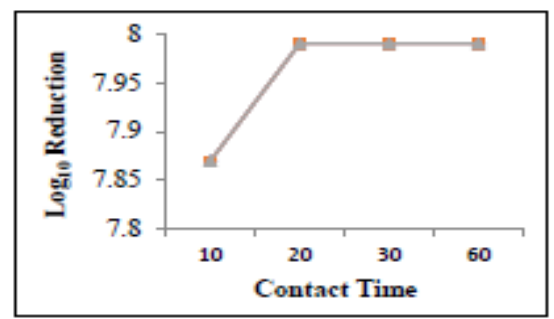

C

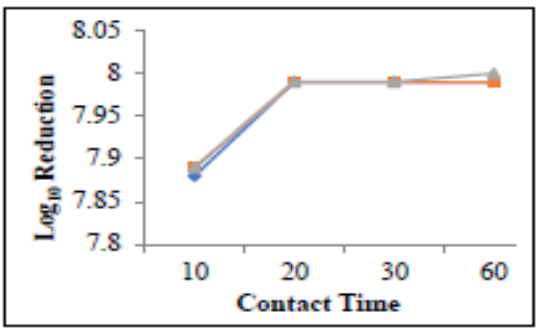

$\mathbf{F}$

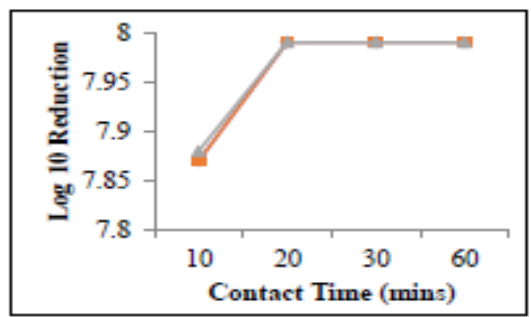

Fig .1: Effect of different concentrations of lodasteryl on (A) Pseudomonas putida FaF12, (B) P. mendocina FaW48, (C) P. stutzeri FaM35, (D) P. aeruginosa FbW30, (E) P. shigelliodes FbM36, (F) P. fluorescens FbC32 

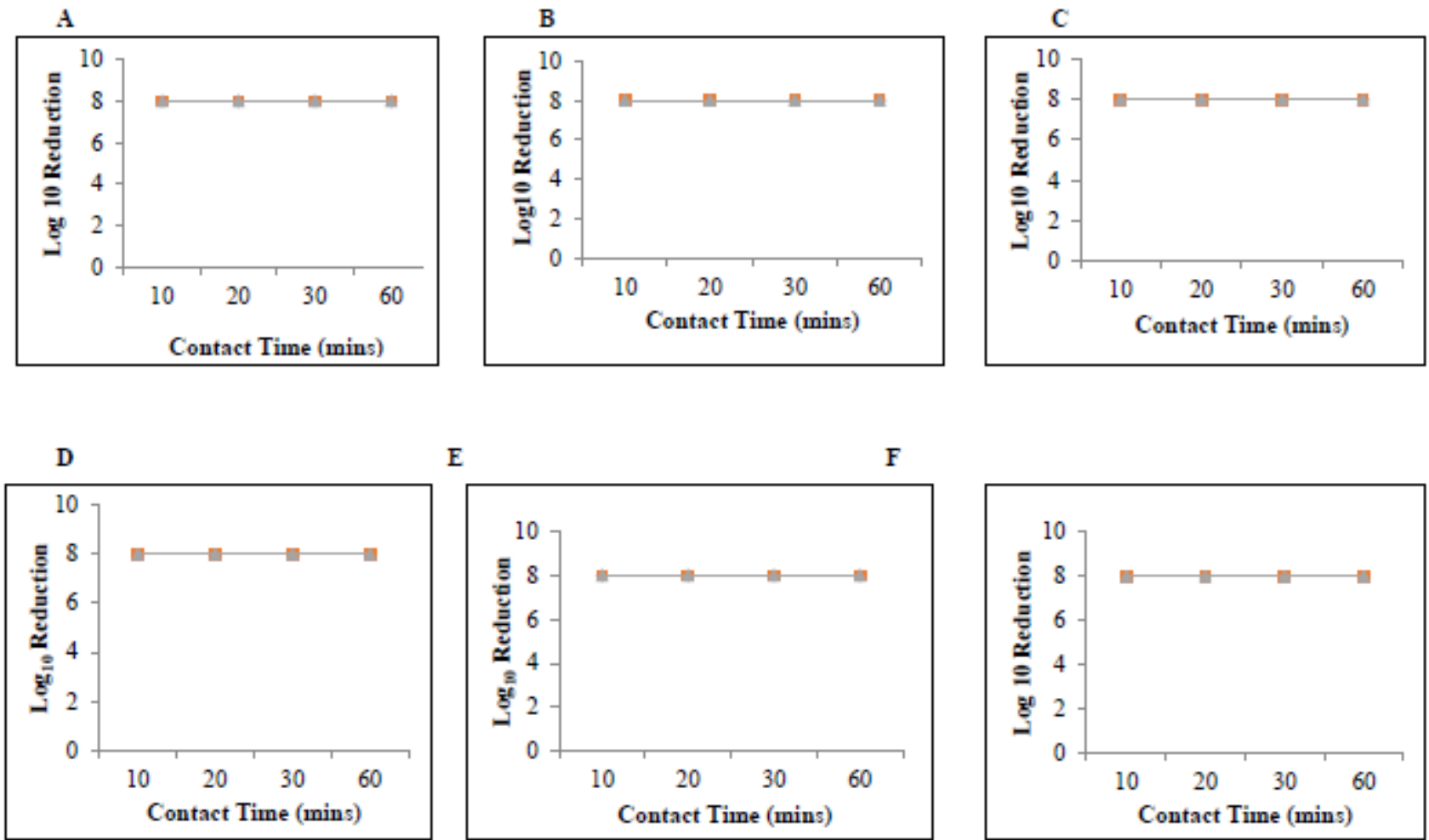

$\square=0.5 \mathrm{x}, \mathrm{X}=1 \mathrm{x}, \quad \Delta=1.5 \mathrm{x}$

Fig.2: Effect of different concentrations of Diskol on (A) Pseudomonas putida FaF12, (B) P. mendocinaFaW48, (C) $P$. stutzeri FaM35, (D) P. aeruginosa FbW30, (E) P. shigelliodes FbM36, (F) P. fluorescens FbC32 


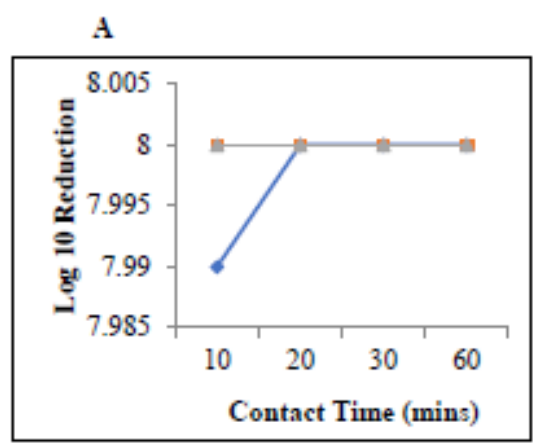

B

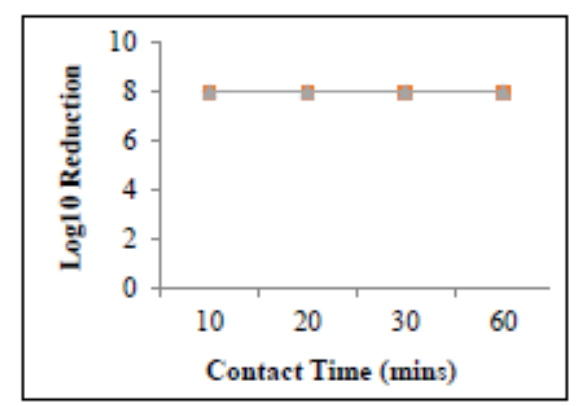

D

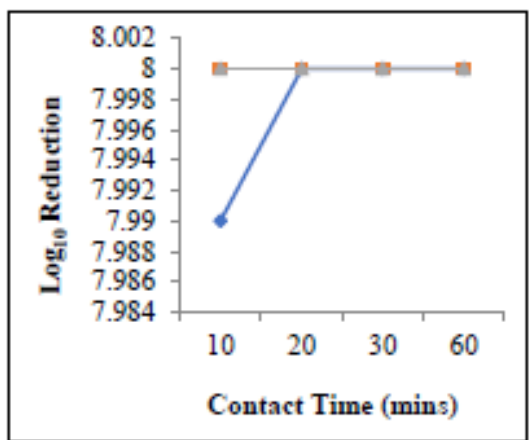

$\square=0.5 \mathrm{x}, \mathrm{X}=1 \mathrm{x}$,

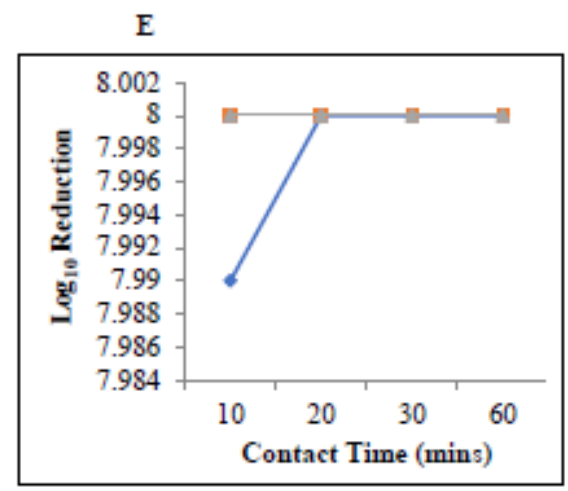

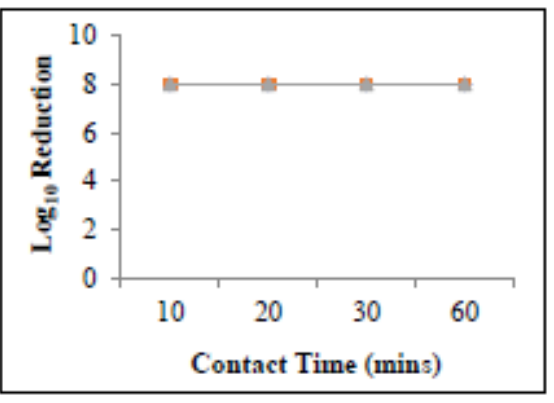

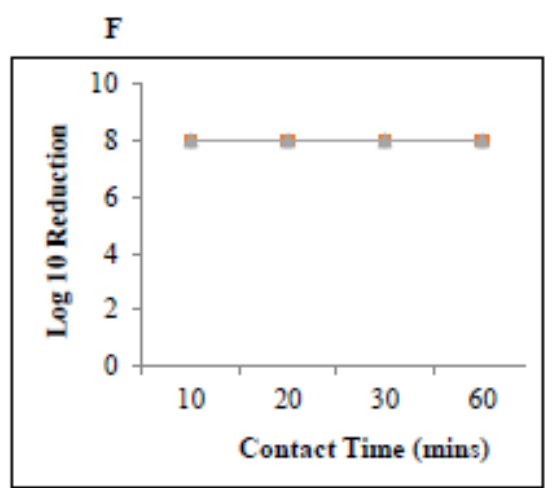

Fig.3: Effect of different concentrations of Morigad on (A) Pseudomonas putida FaF12, (B) P. mendocina FaW48, (C) $P$. stutzeri FaM35, (D) P. aeruginosa FbW30, (E) P. shigelliodes FbM36, (F) P. fluorescens FbC32

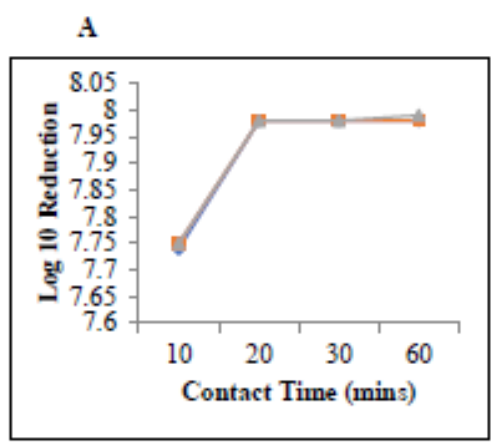

B

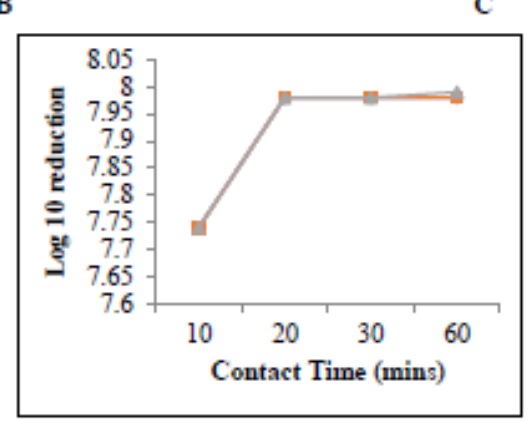

$\mathrm{E}$

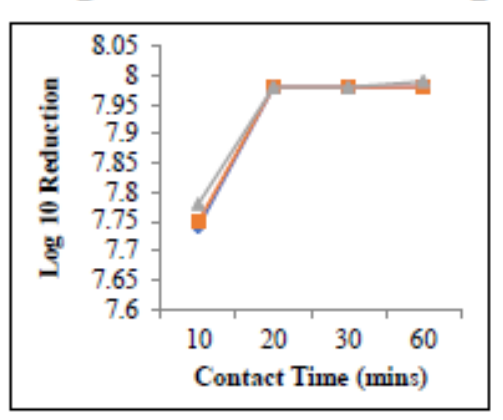

$\square=0.5 \mathrm{x}, \mathrm{X}=\mathrm{lx}, \quad \Delta=1.5 \mathrm{x}$
F
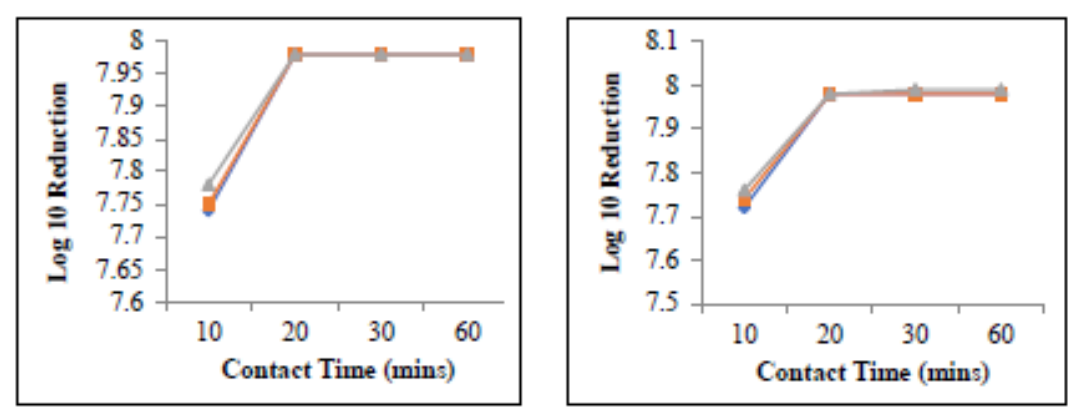

Fig.4: Effect of different concentrations of lodasteryl on (A) Staphylococcus lentus SN1, (B) S. lentus SN2, (C) S. sciuri SN3, (D) S. sciuri SN4, (E) S. aureus SM1, (F) S. aureus SM2

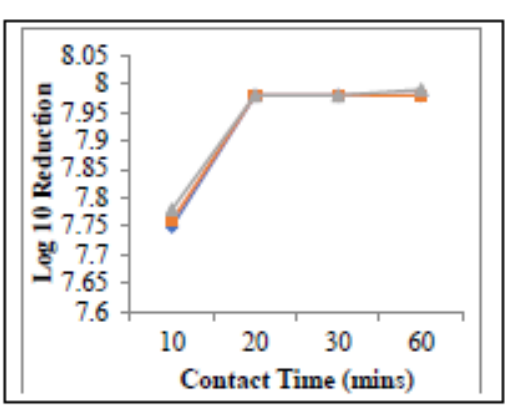




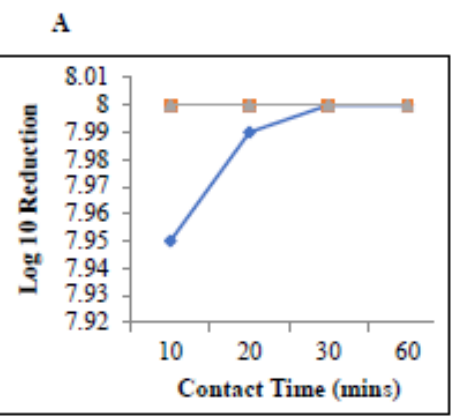

B
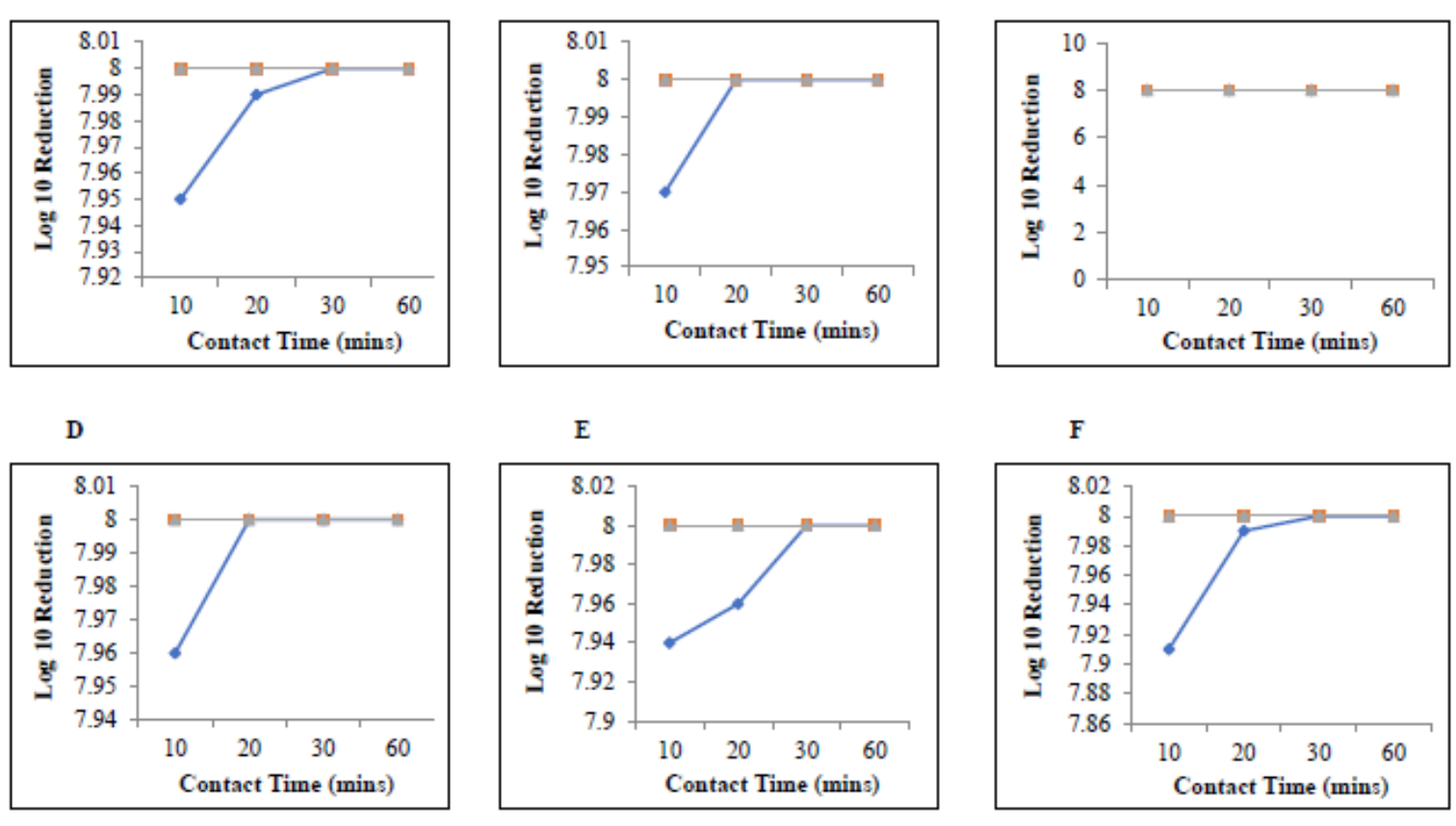

$\square=0.5 \mathrm{x}, \mathrm{X}=1 \mathrm{x}, \quad=\Delta 5 \mathrm{x}$

Fig.5: Effect of different concentrations of Diskol on (A) Staphylococcus lentus SN1, (B) S. lentus SN2, (C) S. sciuri SN3, (D) S. sciuri SN4, (E) S. aureus SM1, (F) S. aureus SM2

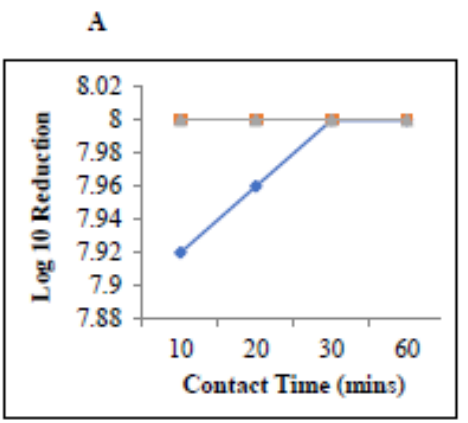

B

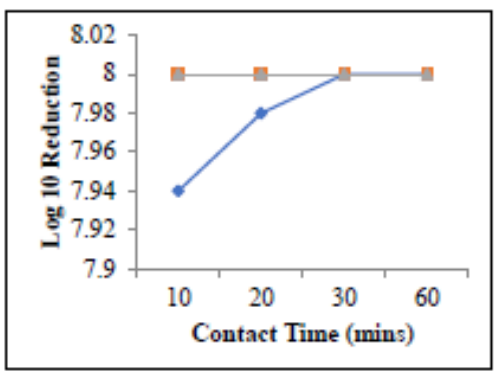

E
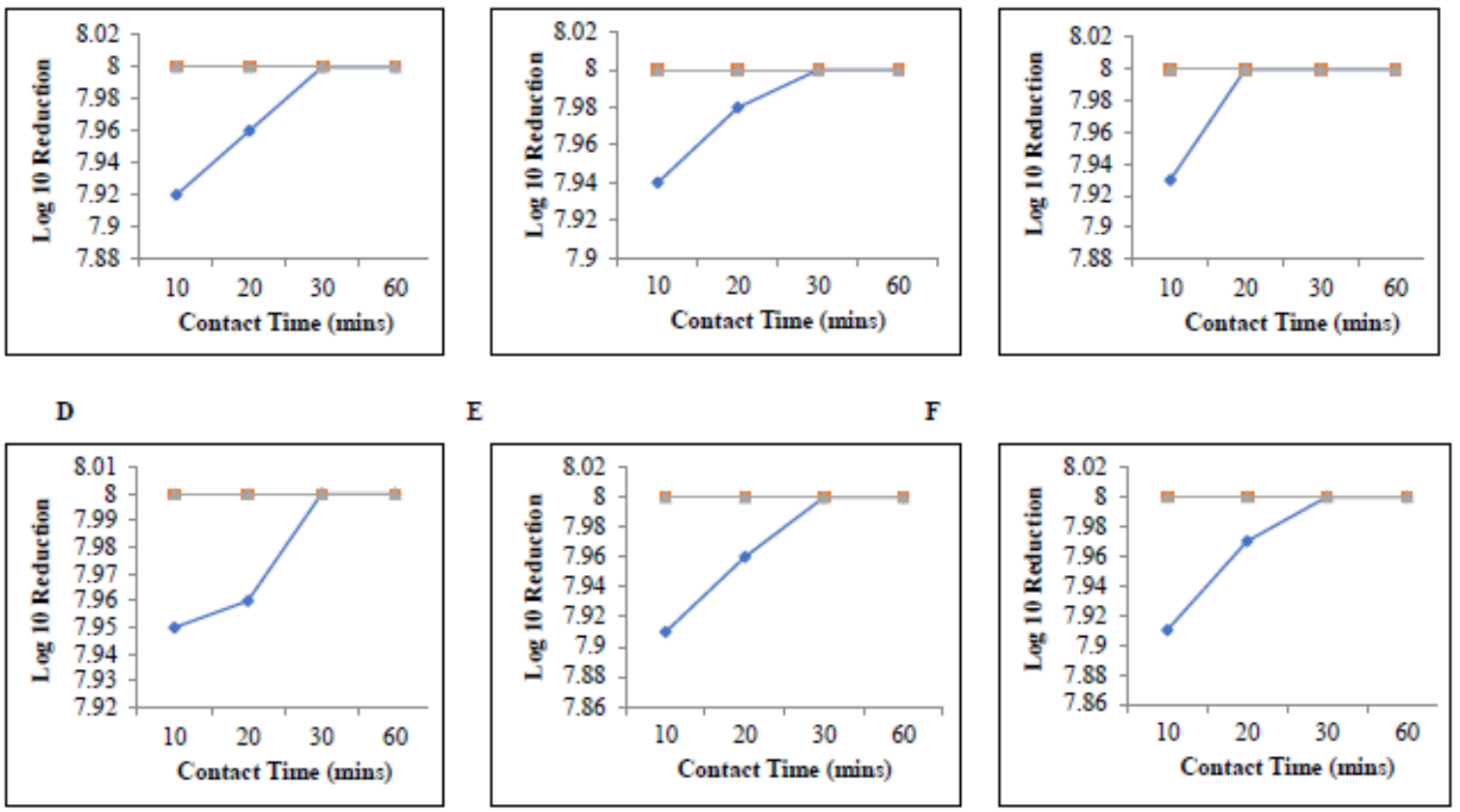

$\square=0.5 \mathrm{x}, \mathrm{X}=1 \mathrm{x}, \quad \Delta=1.5 \mathrm{x}$

Fig.6: Effect of different concentrations of Morigad on (A) Staphylococcus lentus SN1, (B) S. lentus SN2, (C) S. sciuri SN3, (D) S. sciuri SN4, (E) S. aureus SM1, (F) S. aureus SM2 


\section{CONCLUSION}

Diskol and Morigad had comparatively better performance against the test bacteria than lodasteryl but Diskol was the most effective. The results indicated the high inhibitory capacity of Diskol and Morigad and therefore justify their use by poultry farmers for disinfecting poultry houses.

\section{ACKNOWLEDGEMENTS}

We are grateful to the settlers at Aiyedooto Farm Settlement, Ojo, Lagos State for their cooperation during sampling.

\section{AUTHORS' CONTRIBUTIONS}

Grillo, Adebayo designed the study, performed the study protocol with the statistical analysis, arranged the literature searches and wrote the first draft of the manuscript. Olasupo, Nurudeen managed the analysis of the study and proofread the manuscript.

Both authors read and approved the final manuscript.

\section{REFERENCES}

1. Gueye, E. F (2009). The role of networks in information dissemination to family poultry farmers. World Poultry Science Journal 65: $115-124$

2. Awuni, J. A., Coleman, T. K and Sedor, V. B (2005). Comprehensive approach to the improvement of rural poultry production in Ghana. In: Improving farmyard poultry production in Africa: Interventions and their economic assessment. Proceedings of a final research coordination meeting organized by the joint FAO/IAEA Division of Nuclear Techniques in Food and Agriculture and held in Vienna, 24 - 28 May 2004. Pp: 99-106.

3. Food Standards Agency (2011). Foodborne diseases Strategy 2010 - 15. An FSA Programme for the Reduction of Foodborne disease in the UK. Pp: 4.

4. World Health Organisation (2015). WHO's first ever Global Estimates of Foodborne diseases. WHO News Releases $3^{\text {rd }}$ December, 2015. Pp: 2.

5. Ramesh N, Joseph S W, Carr L C, Douglass L $W$ and Wheaton F W (2002). Evaluation of chemical disinfectants for the elimination of Salmonella biofilms from poultry transport containers. Poultry Science. 81: 904-910.

6. Chmielewski, R. A. N and Frank, J. F (2003). Biofilm formation and control in food processing facilities. Comprehensive Reviews in Food Science and Food Safety 2: 22-32.
7. Stringfellow $\mathrm{K}$, Anderson $\mathrm{P}$, Caldwell $\mathrm{D}$, Lee $\mathrm{J}$, Byrd J, McReynolds J, Carey J, Nisbet D, Farnell M (2009) Evaluation of disinfectants commonly used by the commercial poultry industry under simulated field conditions. Poultry Science 88:1151-1155.

8. Sagripanti J and Bonifacino A (1999). Bacterial spores survive treatment with commercial sterilants and disinfectants. Applied Environmental Microbiology 65(9): 4255-4260.

9. Gronholm L, Wirtanen G, Ahlgren K, Nordstrom K, Sjoberg A (1999). Screening of antimicrobial activities of disinfectants and cleaning agents against foodborne spoilage microbes. Z Lebensm Unters Forsch A. 208: 289- 298.

10. Harley JP, Prescott LM (2002) Laboratory Exercises in Microbiology 5th ed New York: McGraw - Hill Companies, Inc.

11. Carballo $\mathrm{J}$ and Araujo, A (2012). Evaluation of the efficacy of commercial sanitizers against adhered and planktonic cells of Listeria monocytogenes and Salmonella spp. Ciência e Tecnologia de Alimentos 32(3): 606612.

12. Moretro, T., Midtgaard, E. S., Nesse, L. L., Langsrud, S (2003). Susceptibility of Salmonella isolated from fish feed factories to disinfectants and air-drying at surfaces. Veterinary Microbiology 94: 207-217.

13. Olonitola, O. S., Fahrenfeld, N., and Pruden, A (2015). Antibiotic resistance Profiles among mesophilic aerobic bacteria in Nigerian chicken litter and associated antibiotic resistance genes. Poultry Science 94: 867874.

14. Adeleke, E. O and Omafuvbe, B. O (2011). Antibiotic resistance of aerobic mesophilic bacteria isolated from poultry faeces. Research Journal of Microbiology 6(4): 356365.

15. Abiala, M., Olayiwola, J., Babatunde, O., Aiyelaagbe, $O$ and Akinyemi, S (2016) Evaluation of therapeutic potentials of plant extracts against poultry bacteria threatening public health. BMC Complementary Alternative Medicine 16: 417-424.

16. Angelillo, I. F., Bianco, A., Nobile, C. G., Pavia, M (1998). Evaluation of the efficacy of glutaraldehyde and peroxygen for disinfection of dental instruments. Letters in Applied Microbiology 27:292-296.

17. Simoes, L. C., Lemos, M., Araujo, P., Pereira, A. $M$ and Simoes, M (2011). The effects of glutaraldehyde on the control of single and dual biofilms of Bacillus cereus and Pseudomonas fluorescens. Biofouling Journal of Bioadhesion and Biofilm Research 27(3): 337-346.

18. Soliman, E. S., Sobeih, M. A. A., Ahmad, Z. H., Hussein, M. M and Moneim, H. A. A (2009). Evaluation of commercial disinfectants 
against bacterial pathogens isolated from broiler farms. International Journal of Poultry Pilotto, F., Rodrigues, L. B., Santos, L. R., Klein, W. A., Colussi, F. M and Nascimento, V. $P$ (2007). Antibacterial efficacy of commercial disinfectants on dirt floor used in poultry breeder houses. Brazilian Journal of Poultry Science 9(2): 127-131.

19. Lamikanra, A. (1989). Disinfection. In: Essential Microbiology. Shaneson, C. I. Ltd, Ibadan, Nigeria. pp. 66-109.

20. Wijesinghe, $L$. $P$ and Weerasinghe, T. L (2010). A Study on the Bactericidal Efficiency of Selected Chemical Disinfectants and Antiseptics. OUSL Journal 6: 44- 58.

21. Ruano, M., El-Attrache, J., Villegas, P (2001). Efficacy comparison of disinfectants used by the commercial poultry industry. Avian Diseases 45:972-977.

22. Okesola, P., Abiola, O., Olola, $\mathrm{O}$ and Aderonke, $F$ (2011). The efficacy of the commonly used hospital disinfectants on Pseudomonas aeruginosa. International Research Journal of Microbiology 2(7): 226229.

23. Grillo, J. A and Ojo, O. Y (2013). Evaluation of activity of dichloroxylenol $(1.2 \% \mathrm{w} / \mathrm{v})$ on
Science 8(8): 728-732.

Staphylococcus aereus Oxoid 701/1 Lot 610254 and clinical isolates of Escherichia coli and Salmonella typhi. African Journal of Microbiology Research 7(33): 4265-4270.

24. Snow, J. B., Wackym, P. A and Bellenger, J. J (2009). Bellenger's Ortorhinolaryncology; Head and Neck Surgery (Revised ed). Shelton, Conn. Peoples Medical Publishing House/ B. C. Decker. Chicago, USA. Pp: 277.

25. Weber, M., Weber, $M$ and Kleine - Boymann, M (2003). 'Phenol' In Ullmann's Encyclopedia of Industrial Chemistry. Wiley - $\mathrm{VCH}$ Weinheim. Pp: $589-604$.

26. Reuss, G., Disteldorf, W., Otto Garner, A and Hilt, A (2002). "Formaldehyde" In Ullmann's Encyclopedia of Industrial Chemistry. Wiley VCH Weinheim. Pp: 